\title{
Hydrogen Sulfide Corrosion of Weld Regions in API X52 Steel
}

\section{Corrosión por ácido sulfhídrico de las regiones de soldadura en acero API X52}

\author{
Arenas-Martínez L.F \\ Facultad de Ciencias Quimicas \\ Universidad Autónoma de Coahuila \\ E-mail:fernando.arenas@uadec.edu.mx
}

\author{
García-Cerecero G. \\ Corporación Mexicana de Investigación en Materiales SA de CV \\ Saltillo, Coahuila \\ E-mail:ggarcia@comimsa.com
}

Information on the article: received: May 2011, accepted: January 2012

\begin{abstract}
The corrosion behavior of gas metal arc welding (GMAW) regions has been studied using potentiodynamic polarization and polarization resistance (LPR) techniques. Experiments were conducted in hydrogen sulfide $\left(\mathrm{H}_{2} \mathrm{~S}\right)$ containing brine and in $\mathrm{H}_{2} \mathrm{~S}$-free brine. Welds were made on API 5L X52 steel. Due to differences in their microstructure, chemical composition and residual stress level, weld regions exhibited different responses under $\mathrm{H}_{2} \mathrm{~S}$ corrosion. Base metal exhibited the highest corrosion rate (CR) and the most cathodic corrosion potential.
\end{abstract}

Se estudió el comportamiento ante la corrosión de las regiones de soldadura de un cordón realizado por arco metálico con gas (GMAW) sobre un acero grado API X52 mediante las técnicas de polarización potenciodinámica y resistencia a la polarización (LPR). Los experimentos se realizaron utilizando salmuera con 300 ppm deácido sulfhídrico $\left(\mathrm{H}_{2} \mathrm{~S}\right)$ y salmuera libre de $\mathrm{H}_{2} \mathrm{~S}$ como electrolitos. Debido a las diferencias en su microestructura, composición química y el nivel de esfuerzos residuales, las regiones de soldadura mostraron diferentes respuestas a la corrosión por $\mathrm{H}_{2} \mathrm{~S}$. El metal base exhibió la velocidad de corrosión (CR) más alta y el potencial de corrosión más catódico.

\section{Keywords:}

- Weld regions

- X52 steel

- hydrogen sulfide

- GMAW

- corrosion

\section{Descriptores:}

- regiones de soldadura,

- acero X52,

- ácido sulfhídrico,

- GMAW,

- corrosión 


\section{Introduction}

Hydrogen sulfide corrosion is one of the most important sources of concern in the gas and oil transport industry. Over several decades, a considerable amount of literature has been published on this topic (Smith and Pakalapati, 2004). Pipelines used for oil and gas transport are manufactured by welding segments of carbon steel pipe. Welding seams can be divided into three regions: the weld metal (WM), the heat affected zone (HAZ) and the base metal (BM). These regions differ in their microstructure, chemical composition and residual stress level. A variety of corrosion types, like sulfide stress cracking (SCC) and hydrogen-induced cracking (HIC), affect the steel weldment used in sour environments (Makarenko and Khalin, 2005; Tsay et al., 2001).

However, SSC and HIC are not the only types of corrosion to which welds are exposed. Electrochemical corrosion by $\mathrm{H}_{2} \mathrm{~S}$ also occurs on the welds and clearly plays an important role in the deterioration of pipeline joints. The following redox reaction describes this process

$\mathrm{Fe}+\mathrm{H}_{2} \mathrm{~S} \rightarrow \mathrm{FeS}+\mathrm{H}_{2}$

In most of the cases, $\mathrm{H}_{2} \mathrm{~S}$ presence increases the $\mathrm{CR}$ but, at low concentrations and prolonged immersion times, $\mathrm{H}_{2} \mathrm{~S}$ has an inhibition effect due to the formation of a ferrous sulfide (FeS) protective film (Ma et al., 2000). Other studies (Fragiel et al., 2005; Pound et al., 1989; Brown et al., 2003; Genescá and Arzola, 2003), have considered the electrochemical $\mathrm{H}_{2} \mathrm{~S}$ corrosion of carbon steel and the susceptibility of welds to SSC (Kobayashi et al., 1986; Zhao et al., 2003; Radkevych, 1999) but, to our knowledge, no corrosion analysis of the weld regions has been performed on X52 steel in sour environment for electrochemical corrosion. The aim of this work is to determine the specific response of each weld region to $\mathrm{H}_{2} \mathrm{~S}$ corrosion.

\section{Experimental procedure}

The welds were made by gas metal arc welding (GMAW) with E71T-1 flux-cored wire of $0.114 \mathrm{~cm}\left(0.045^{\prime \prime}\right)$ caliber at a speed of $0.254 \mathrm{~cm} / \mathrm{s}$. The electrode was fed at $14.816 \mathrm{~cm} / \mathrm{s}$. The welding was performed at $25 \mathrm{~V}$ and 190 A with a calculated heat input of $18.75 \mathrm{KJ} / \mathrm{cm}$.

Metal samples were obtained from the weld regions and used as working electrodes. The samples were cut from a piece of welded tube with disk cutter at a speed of $0.15 \mathrm{~mm} / \mathrm{s}$ and $3400 \mathrm{rpm}$. The specimens were groun- ded with SiC 240-600 grit paper in a polishing wheel and mounted in thermoplastic resin. A stainless steel screw was connected from the working electrodes to the electrochemical circuit. The exposed surface of the working electrodes was prepared by polishing with $\mathrm{SiC}$ grit paper, cleaned with deionized water and acetone, and dried with hot air. Surface areas were calculated using the dimensions obtained with a calibrated vernier caliper. A calibrated pycnometer was used to determine sample's densities.

The metallographic specimens were prepared in a similar way. Transverse segments of the studied welds were cut in order to observe all weld regions. Once the specimens were polished with $\mathrm{SiC} 240-600$ grit paper, the specimens were polished with diamond paste of 1 $\mu \mathrm{m}$ until a mirror-like surface was obtained. Just before the microscopic observation, the specimens were attacked with Nital $\left(10 \% \mathrm{HNO}_{3}\right.$ in absolute ethanol), rinsed with ethanol and acetone, and dried with hot air. Microstructure images were obtained with a metallographic optical microscope.

Electrochemical experiments were performed in a three-electrode cell with a graphite rod as auxiliary electrode and an $\mathrm{Ag} / \mathrm{AgCl}$ electrode as reference. A Solartron SI 1287 potentiostat was used for the potentiodynamic polarization and LPR tests. CorrWare and CorrView version 2.9 were used to process and visualize data. The potential sweeps were performed over a range of -0.1 to $0.1 \mathrm{~V}$ (vs $\mathrm{Ag} / \mathrm{AgCl}$ ) from open cell potential at a constant rate of $0.1 \mathrm{mV} / \mathrm{s}$. Working electrodes were immersed in the electrolyte for 5 minutes before the potential sweeps. All the experiments were carried out at room temperature $\left(25^{\circ} \mathrm{C}\right)$. The corrosion current $I_{\text {corr }}$ was calculated from the linear polarization resistance $R_{p}$ in the Stern-Geary equation

$$
I_{\text {corr }}=\frac{b_{a} b_{c}}{2.23\left(b_{a}+b_{c}\right) R_{p}}
$$

where $b_{a}$ and $b_{c}$ are the Tafel slopes. $I_{\text {corr }}$ can be related directly to the corrosion rate CR (in millimeters per year) through the following equation

$C R=\frac{0.13 l_{\text {corr }}(E . W .)}{d}$

where E.W. is the equivalent weight of the corroding species and $d$ is the density of the corroding species in $\mathrm{g} / \mathrm{cm}^{3}$.

The electrolyte solutions were prepared by the addition of $10.700 \mathrm{~g}$ of $\mathrm{NaCl}, 0.339 \mathrm{~g}$ of $\mathrm{CaCl}_{2}$ and $0.207 \mathrm{~g}$ of $\mathrm{MgCl}_{2} \cdot 6 \mathrm{H}_{2} \mathrm{O}$ in 1 liter of deionized water, according to 
the procedure detailed in NACE standard 1D182 (2005) (NACE Technical Publication 1D182, 2005). Dissolved oxygen was removed by bubbling nitrogen $(99.9 \%$ pure) through the cell for 30 minutes before the tests. For experiments in sour environment, $\mathrm{H}_{2} \mathrm{~S}$ was synthesized in the above solution by the addition of $0.170 \mathrm{~g}$ of acetic acid and $0.353 \mathrm{~g}$ of $\mathrm{Na}_{2} \mathrm{~S}$ to 1 liter of brine. This technique yielded approximately $300 \mathrm{ppm}$ of $\mathrm{H}_{2} \mathrm{~S}$, according to the results of an indirect iodometric titration. This method is described in NACE Standard TM02842003 (NACE Standard TM0284, 2003).

\section{Results and discussion}

Metallographic analysis

As shown in Figure 1, the welding metal shows the acicular ferrite columnar grains found in common carbon steel welds. HAZ is composed of refined grains of ferrite-pearlite (Figure 2), product of the transformation of base metal with the heat provided by the welding process. The base metal consists of equiaxed grains of ferrite-pearlite, typical in all carbon steels (Figure 3).
Potentiodynamic polarization and LPR in Brine

Polarization curves of each weld region are shown in Figure 4. Each material exhibited a characteristic corrosion behavior (Table 1). Weld metal presents the most anodic $\mathrm{E}_{\text {corr }}$ value; therefore, it is the least thermodynamically favored region for corrosion attack. HAZ and base metal exhibited more cathodic values, being more susceptible to corrosion. Interestingly, HAZ and base metal have similar $\mathrm{E}_{\text {corr }}$ values. However, there is a significant difference between the responses of these regions. The base metal exhibits uniform $\mathrm{E}_{\text {corr }}$ values, while HAZ $\mathrm{E}_{\text {corr }}$ values are scattered. This could be interpreted as evidence of the corrosion mechanism occurring on the electrodes. Scattered $E_{\text {corr }}$ values are an indication of localized corrosion pitting (Videm and Kvarekval, 1995). Table 2 shows that CR values exhibited by the base metal are larger than those corresponding to the weld metal and the HAZ.

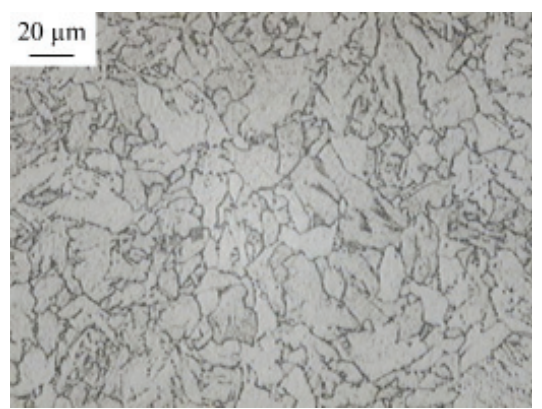

Figure 1. Base metal microstructure of a GMAW weld on API X52 steel. Magnification 500x

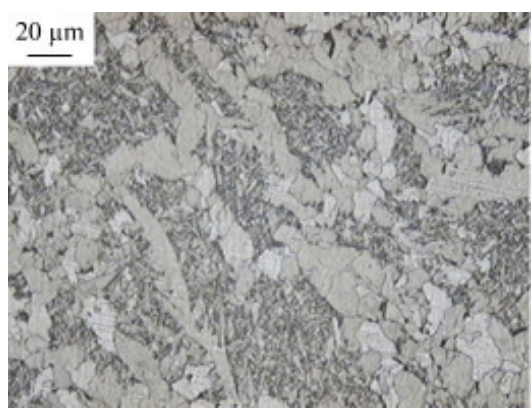

Figure 2. Weld metal microstructure of a GMAW weld on API X52 steel. Magnification 500x

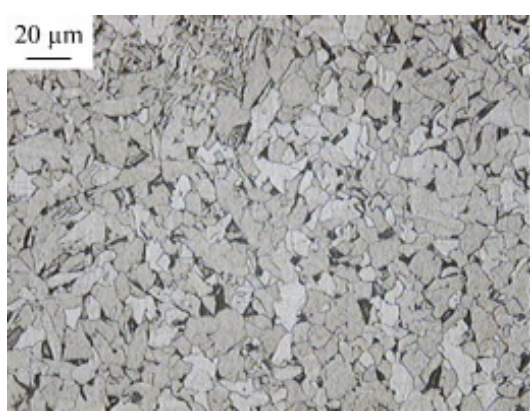

Figure 3. HAZ microstructure of a GMAW weld on API X52 steel. Magnification $500 x$

\begin{tabular}{cccc}
\hline Electrolyte & WM & HAZ & BM \\
\hline \multirow{2}{*}{ Brine } & -0.432 & -0.504 & -0.526 \\
& -0.435 & -0.518 & -0.524 \\
& -0.453 & -0.549 & -0.525 \\
Brine with 300 ppm & -0.775 & -0.790 & -0.800 \\
of $\mathrm{H}_{2} \mathrm{~S}$ & -0.775 & -0.791 & -0.799 \\
& -0.777 & -0.783 & -0.795 \\
\hline
\end{tabular}

Table 1. Corrosion potentials (V) of weld regions in a GMAW weld on API X52 steel 


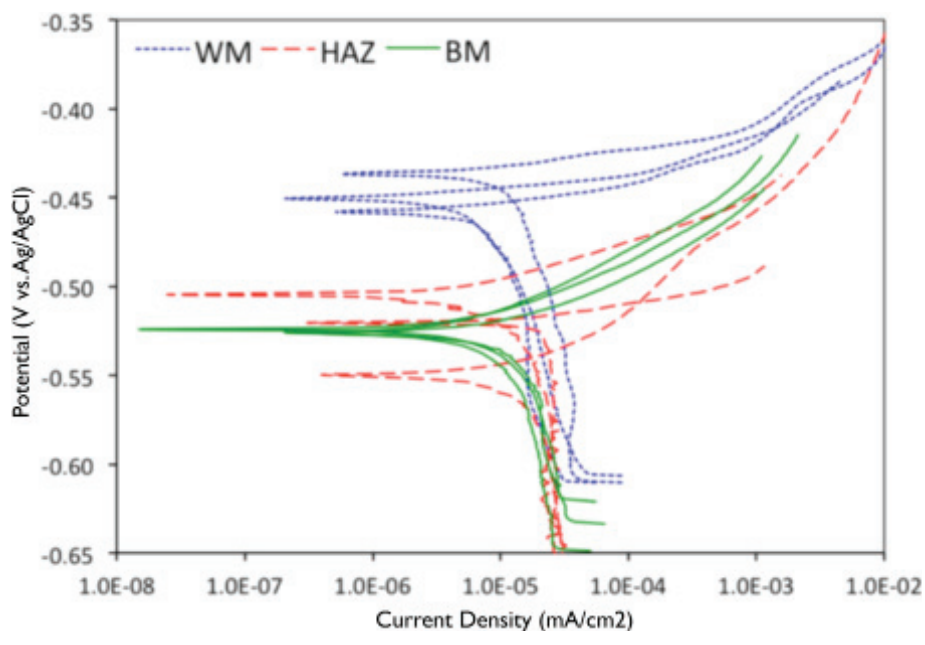

\begin{tabular}{cccc}
\hline Electrolyte & WM & HAZ & BM \\
\hline \multirow{2}{*}{ Brine } & 0.108 & 0.138 & 0.217 \\
& 0.078 & 0.213 & 0.172 \\
& 0.062 & 0.102 & 0.132 \\
Brine with 300 & 0.067 & 0.026 & 0.083 \\
ppm of $\mathrm{H}_{2} \mathrm{~S}$ & 0.085 & 0.054 & 0.106 \\
& 0.064 & 0.028 & 0.186 \\
\hline
\end{tabular}

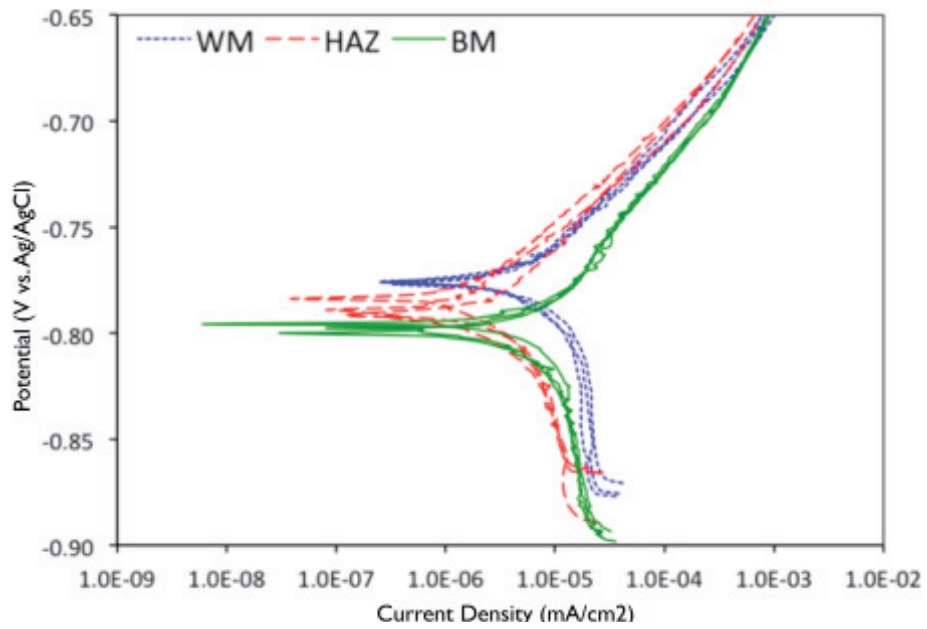

Figure 4. Potentiodynamic curves of weld regions in a GMAW weld on API X52 steel. Results obtained in $\mathrm{H}_{2} \mathrm{~S}$-free brine

Table 2.Corrosion rates ( $\mathrm{mm} /$ year) of weld regions in a GMAW weld on API X52 steel
Potentiodynamic polarization and LPR in Brine with 300 ppm $\mathrm{H}_{2} \mathrm{~S}$

Figure 5 shows the polarization curves of the different weld regions in presence of $300 \mathrm{ppm}$ of $\mathrm{H}_{2} \mathrm{~S}$. $\mathrm{E}_{\text {corr }}$ values show very little dispersion and the order of susceptibility is quite clear (Table 1 ). The small dispersion of the $\mathrm{E}_{\text {corr }}$ values of the HAZ can be attributed to a process moderate pitting. As in the $\mathrm{H}_{2} \mathrm{~S}$-free brine tests, the weld metal has the most anodic $\mathrm{E}_{\text {corr }}$ value. HAZ has an intermediate $E_{\text {corr }}$ value while the base metal $\mathrm{E}_{\text {corr }}$ is the most cathodic.

Table 2 shows the results of LPR for the weld regions in the presence of $300 \mathrm{ppm}$ of $\mathrm{H}_{2} \mathrm{~S}$. The HAZ presents the lowest CR. All the weld regions presented lower CRs in $\mathrm{H}_{2} \mathrm{~S}$-containing solution than in the brine. These results are consistent with the findings of Galvan et al., 2003). 


\section{Conclusions}

When a GMAW weld on X52 steel is subjected to electrochemical corrosion attack by $\mathrm{H}_{2} \mathrm{~S}$, the base metal shows the higher corrosion rate and the most cathodic corrosion potential of weld regions. The weld metal and HAZ are more resistant to electrochemical corrosion by $\mathrm{H}_{2} \mathrm{~S}$ than the rest of the steel pipe. The HAZ presents no special susceptibility to electrochemical corrosion by $\mathrm{H}_{2} \mathrm{~S}$, the latter having an intermediate value between the base metal and weld metal. Weld regions showed higher corrosion rates in the presence of $\mathrm{H}_{2} \mathrm{~S}$. However, their $\mathrm{E}_{\text {corr }}$ values were more anodic in the $\mathrm{H}_{2} \mathrm{~S}$-free brine, which means they are more susceptible to corrosion in this environment.

\section{Acknowledgments}

The financial support provided by COMIMSA (Mexico) is gratefully acknowledged. Thanks are also given to the FIME corrosion laboratory team at the Autonomous University of Nuevo León (México) for their technical support.

\section{References}

Brown B., LeeK L. et al. Corrosion in Multifase Flow Containing Small Amounts of H2S. Corrosion-2003, San Diego (Ca), NACE International: Paper 03341.

Fragiel A., Serna S., Pérez R. Electrochemical Study of Two Microalloyed Pipeline Steels in $\mathrm{H}_{2} \mathrm{~S}$ Environments. International Journal of Hydrogen Energy, volume 30 (issue 12), 2005: 13031309.

Galván R., Genescá J. et al. Effects of Turbulent Flow on the Corrosion Kinetics of X52 Pipeline Steel in Aqueous Solutions Containing $\mathrm{H}_{2} \mathrm{~S}$. Materials and Corrosion, volume 55 (issue 8), 2003: 586-593.

Genescá J., Arzola S. Electrochemical Study on the Corrosion of X70 Pipeline Steel in $\mathrm{H}_{2} \mathrm{~S}$ Containing Solutions. Journal of Solid State Electrochemistry, volume 9 (issue 4), 2003: 197-200.

Kobayashi Y. et al. The Resistance of Welded Landpipes to Sulfyde Stress Cracking. Corrosion Science, volume 27 (issues 10-11), 1986: 1117-1135.

Ma H., Cheng X. et al. The Influence of Hydrogen Sulfide on Corrosion of Iron Under Different Conditions. Corrosion Science, volume 42 (issue 10), 2000: 1669-1683.
Makarenko V.D., Khalin A.N. Effects of Hydrogen on the Corrosion Failure of Welded Landpipes. Chemical and Petroleum Engineering, volume 41 (issues 7-8), 2005: 448-450.

NACE Technical Publication 1D182. Wheel Test Method Used for Evaluation of Film-Persistent Corrosion Inhibitors for Oilfield Applications. NACE International, 2005.

NACE Standard TM0284-2003. Standard Test Method. Evaluation of Pipeline and Pressure Vessel Steels for Resistance to Hydrogen-Induced Cracking. NACE International, 2003.

Pound B.G., WrightG.A. et al. The Anodic Behavior of Iron in Hydrogen Sulfide Solutions. Corrosion, volume 45 (issue 5), 1989: 386-392.

Radkevych O.I. Effect of the Chemical Composition of Welds of Pipelines on their Resistance to Crack Propagation in Hydrogen Sulfide Environments. Materials Science, volume 35 (issue 1), 1999: 108-117.

Smith S.N.,Pakalapati R. Thirty Years of Downhole Corrosion Experience at Big Escambia Creek: Corrosion Mechanisms and Inhibition. Corrosion-2004, New Orleans (L.A), NACE International: Paper 04744.

Tsay L.W. et al. Sulfide Stress Corrosion Cracking and Fatigue Crack Growth of Welded TMCP API 5L X65 Pipe-Line Steel. International Journal of Fatigue, volume 23 (issue 2), 2001: 103113.

Videm K., Kvarekvål J. Corrosion of Carbon Steel in Carbon Dioxide-Saturated Solutions Containing Small Amounts of Hydrogen Sulfide. Corrosion, volume 51 (issue 4), 1995: 260-269.

Zhao M.C., Tang B., Shang Y.Y., Yang K. Role of Microstructure on Sulfide Stress Cracking of Oil and Gas Pipeline Steels. Metallurgical and Materials Transactions, volume 34 (issue 5), 2003: 1089-1096.

\section{Citation for this article}

Chicago citation style

Arenas-Martínez, Luis Fernando, Gabriel García-Cerecero. Hidrogen Sulfide Corrosion of Weld Regions in API 52 Steel. Ingeniería Investigación y Tecnología XIII, 04 (2012): 473-478.

\section{ISO 690 citation style}

Arenas-Martínez L.F., García-Cerecero G. Hidrogen Sulfide Corrosion of Weld Regions in API X52 Steel. Ingeniería Investigación y Tecnología, volumen XIII (número 4), octubre-diciembre 2012: 473-478 


\section{About the authors}

Luis Fernando Arenas-Martínez. Is a postgraduate student in Chemistry at the Autonomous University of Coahuila, pursuing a M.S. through a scholarship from the National Council on Science and Technology of Mexico (CONACYT). Research interests include inorganic chemistry, electrochemistry and corrosion science.

Gabriel García-Cerecero. Is a professor of metallurgy at the Postgraduate Studies Department in COMIMSA (Mexico), teaching students of the Master's Program in Industrial Welding Technology. He is a Metallurgical Engineer graduated from Saltillo Technological Institute. He received his M.S. in nonferrous metallurgy from CINVESTAV Saltillo of the National Polytechnic Institute (IPN). Before joining COMIMSA, worked in several metallurgical companies, including SICARTSA and CIFUNSA. He was a Certified Associate Welding Inspector from July 2001 to July 2004. His research interests are in the corrosion and failure analysis of oil and gas pipelines. 